\title{
Determining New Markets Using Analytic Hierarchy Process: Case Study in Güral Porcelain
}

\author{
Habibe Yelda Şener ${ }^{1}$ \\ ${ }^{1}$ Kütahya Vocational School of Social Sciences, Dumlupinar University, Kütahya, Turkey \\ Correspondence: Habibe Yelda Şener, Kütahya Vocational School of Social Sciences, Dumlupinar University, \\ Kütahya, 43100, Turkey. Tel: 90-274-227-0450. E-mail: yeldasener@gmail.com
}

Received: July 25, $2014 \quad$ Accepted: August 6, $2014 \quad$ Online Published: September 28, 2014
$\begin{aligned} & \text { doi:10.5539/ijms.v6n5p149 } \quad \text { URL: http://dx.doi.org/10.5539/ijms.v6n5p149 }\end{aligned}$

\begin{abstract}
The aim of this study is to solve the problem of determining the most appropriate new market upon which Güral Porcelain, a Turkish ceramic company exporting to various countries, will invest within the scope of market development strategy. In accordance with the purpose of the study, analytic hierarchy process (AHP), which enables to choose the most appropriate one among the alternatives by using both numeric and nonnumeric criteria, was used. The study was carried out together with Güral Porcelain Export Department Executive. Total eight main criteria were determined in the study: operating assets, communication infrastructure of the target market, economic growth rate, proximity to other markets, competitive advantage in the target market, demand, functioning of the legal system and trade agreements with the target market-exemption. After paired comparison of the main criteria, their relative importance values were determined. According to these significance values, it was seen that the criterion of "demand in the target market" was the most crucial criterion in choosing the new market to invest on for Güral Porcelain. Relative importance values of the alternatives were computed and the most suitable new market for Güral Porcelain to invest was determined to Northern Iraq. This was presented to the Güral Porcelain Export Department Executive. In this study, the most appropriate market for Güral Porcelain to invest was determined using AHP. Thus, decision makers seeking for new markets to raise their brand value in global porcelain sector were guided in determining the most suitable target market.
\end{abstract}

Keywords: growth strategy, Ansoff matrix, market development, market selection, Analytic Hierarchy Process (AHP)

\section{Introduction}

Strategic change process is determined using the data acquired from the interaction between strategies and environmental elements, business structure and dynamics (Ansoff, 1987:514; Lombriser and Ansoff, 1995:95-108). In this context, according to Ansoff (1977:58-77), trade environment in the market, state subsidies, political environment, job safety and constraints, market resistance and potential, laws, social norms, resources and background information, business structure, capabilities and culture should be analysed. Ansoff (1975:26) claims that these three main elements in strategic change improve awareness and approach of the business, enhance its flexibility and enable its development by making the right move to opportunities and against threats.

Growth is a crucial performance criterion and success scale for businesses (Skrt, 2004:108). Due to the powerful effect of competition, business executives aim to grow by launching new products, adding additional values to existing products and acquiring new markets (Porter, 1996:6-17). In order for businesses to grow, they should possess certain principles. Businesses should provide presentations at the right time and place to the right customers involving existing or new products that will meet the customer needs through new processes and appropriate distribution paths, will do them some good and will be able to be differentiated from rival products. Within this process, the following are important: innovation in product production and delivery, pursuing the opportunities that could give competitive advantage, sustainability, a clear vision, long-term strategies, effective risk management, a successful administration and profitability (McKaskill, 2010:4-7)

Ansoff (1965:163-164) emphasizes that businesses are affected by their environment and should defined the main environmental elements to plan their activities. Within the scope of this definition, the product dynamics should be analysed first. Technologic development, increase in customer demands and product innovations have become important tools for businesses to acquire competitive advantage and for their growth. Also, businesses 
are in search of new markets for their existing and/or new products. Cilley (2011:32) states that the market penetration, product development, market development and diversification strategies in Ansoff matrix give businesses cost efficiency and provide them with the best growth opportunities. Businesses wanting to grow in international markets adopt market development strategy and have to decide upon the best market to invest. There are numerous criteria in choosing a market to invest like market size, its growth rate and technologic development, the business's existing and potential market share, appropriateness to business strategies, the business's capabilities in product features and delivery, its coherence to distribution channels in the market, its achieving sustainable competitive advantage, easy access to customers, its coherence to marketing programs, its image and risk level that it can cope with (Callaghan \& Morley, 2002:765) In this study, the most suitable new market for Güral Porcelain to invest within the scope of market development strategy was determined using Analytic Hierarchy Process (AHP).

The study is comprised of five sections. In the first section, the problem of new market for Güral Porcelain to invest within the scope of market development strategy is explained. In the second section, Ansoff matrix, which can be used by businesses while determining their growth strategies, is explained. In the third part, AHP, used while deciding upon the new market, and application in marketing area are analysed. In the fourth part, the hierarchy model for Güral Porcelain to choose the most suitable market to invest, analytic applications and research findings are presented. The last section presents assessment of the results.

\section{Literature Review}

\subsection{Determining Growth Strategies of Businesses: Ansoff Matrix}

Strategy selection involves understanding of the basics of strategic decisions to be followed by businesses both at corporate level and in terms of their departments. The alternatives businesses will determine for growth strategies emphasize the points to advance and their course of action. In the process of strategy selection, businesses should define the rudiments, where they will have competitive advantage, in terms of market, customer and business capabilities (Johnson, Scholes, \& Whittington, 2005:18-23).

Management of business strategies covers four stages; strategy analysis in which external environment and in-business capabilities are assessed, defining strategies, application of strategies and performance evaluation. Doing external environment analysis during strategy analysis allows determining strategies by determining the evolving environmental conditions and taking the likely risks into account. In this process, PESTLE analysis and Porter analysis provide insights for future opportunities and threats. MOST analysis, used in the evaluation of in-business capabilities, determines the main capabilities of a business and opportunities for its success. The stage of defining strategies aims to reveal the conditions a business face with and to determine the course of action accordingly thanks to out-of-business environmental analysis and determination of in-business capabilities. In this process, SWOT analysis and Ansoff matrix are used. The main challenge at the stage of strategy application is the need for coordination to conduct the required alterations when the business is aware of the process of strategy application and when some alterations are needed for the success of the business. Performance evaluation is based on the need for evaluating the performance of the business. The techniques, used at this stage, which allow defining performance scales and evaluation are critical success factors/key performance indicators and balanced score cards (Cadle et al., 2010:3-21).

Defining business strategies determines the way the growth decisions will go. The two key elements in businesses' determining growth strategies are product and market. A product is a value presented to customers by a business. Depending on time and changing market conditions, changes and upgrades are required on the product. Market is classified and assessed according to different criteria. Success of growth strategies depends on coherence to market conditions (Lowy \& Hood, 2004: 135). In terms of business, growth enables development and success in evolving markets by taking opportunities (Aaker \& McLoughlin, 2010:5-6). In this context, certain factors should be taken into account while determining growth strategies for businesses. First of all, economica, political, international trends and trends in the industry of activity should be analysed. Competitive power of the business should be determined. Business performance that will serve application of growth strategies should be improved, production costs should be monitored and kept under control (Ansoff, 1957:114-115).

Fig. 1 presents Ansoff matrix used in defining growth strategies of businesses. Crosby (2012:12) characterized the strategies in Ansoff matrix in terms of risks. In this evaluation, he defined market penetration strategy as "low risk", market and production development strategies as "moderate risk" and diversification strategy as "high risk". 
Existing Market

New Market
Existing Product New product

\begin{tabular}{|l|l|}
\hline $\begin{array}{l}\text { Market Penetration } \\
\text { Strategy }\end{array}$ & $\begin{array}{l}\text { Product Development } \\
\text { Strategy }\end{array}$ \\
\hline $\begin{array}{l}\text { Market Development } \\
\text { Strategy }\end{array}$ & $\begin{array}{l}\text { Diversification } \\
\text { Strategy }\end{array}$ \\
\hline
\end{tabular}

Figure 1. Ansoff growth matrix

\subsubsection{Market Penetration Strategy}

Market penetration is defined as a business's growth in the existing market with its existing products. This strategy urges customers to buy more frequently and buy more products at every purchasing (Kotler, 2003:73). This strategy depends on predicting whether a business will be able to get a bigger market share in the existing market with its existing products. Success in market penetration depends on existing customers' buying more products more frequently, gaining rivel business's customers and persuading potential customers who haven't purchased from that business yet to do some purchasing (Kotler, 2000:75). If businesses can form strong relations with customers, customers' purchasing frequency and amount can be increased; besides, by existing customers' recommending the business and its products to their vicinity, new customers can be acquired with no cost (Şener \& Behdioğlu, 2013:167). Market penetration strategy enables to access to such local resources as distribution networks in the target market, local businesses and authorities (Meyer \& Tran, 2006:179). However, increasing influence in foreign markets might also cause businesses to bear more marketing costs (Arkolakis, 2008: 31).

\subsubsection{Product Development Strategy}

Today's competititve pressure makes it necessary for businesses to go into markets with different products and attempt to increase their market share (Preston, 1990:11). It is important for businesses to develop new products to get competitive advantage. Within the process of developing new products, being ready for changes, forming project teams, determining product development stages, efficient auditing and being a learner organisation are all required (Takeuchi \& Nonaka, 1986:137-146). Also, the process of product development should be evaluated from various perspectives like preferences of product users, competition level at the market, rival product designs, functional capabilities of the business, technical superiorities and price determination criteria (Gotzsch, Chanaron \& Birhall, 2006: 1-15, Yelkur \& Herbig, 1996:38-43).

In this context, businesses' being able to form close relations with their customers enables the business to learn about customer expectations, determine the market trends and monitor the rival businesses' presentations. These findings affect the new product manufacturing of businesses positively (Yli-Renko \& Janakiraman, 2008:144). Product development decisions of businesses are also affected by the needs of industrial applications. On the other hand, existence of product development organisations in businesses enables team members to determine the process for product development and find out productivity-enhancing tools. Performance evaluation of the team and exposing the employees to a rewarding system show that product development has been shaped withing a social system and environment (Krishnan \& Ulrich, 2001:1-21).

If businesses can manage their time, efforts, tangible assets and employees accurately, product development strategy generally results in success. Not understanding or accepting the good product ideas during product development activities might lead to missing many opportunities. Also, allocating resources with inappropriate ideas might cause problems for the business. On the other hand, the cost of routine activities of the business might affect product development negatively. In this context, the most crucial challenges in developing product development strategies are executives' inability to define strategies for innovation and their not knowing clearly how to formulate new product strategies (Crawford, 1972:49-58). For product development, innovation strategies are required and innovation strategies should be coherent with the business's aims and targets. In this process, aims for product innovation should be defined clearly, the role of product innovation should be determined within the business aims, strategic areas to be focused on should be determined and necessary resources should be allocated from the budget (Cooper \& Edgett, 2010:33-40).

\subsubsection{Diversification Strategy}

Efficiency of a business in market research is developing its market with new products (Kumar, 2010:96). Diversification strategy requires using new techniques, new capabilities and qualities for original products. It also necessitates physical and organizational changes in the business structure and bears very different 
characteristics than its past experience (Ansoff, 1957:114). With diversification strategy, a business can perform different activities in various industries in the long-term. The business, however, should be careful in this process while deciding which activities to sustain and which ones to quit. Characteristics of diversification strategy are effective on the corporate structure and contribute to formation of a decentralist structure (Chandler, 1959:73).

\subsubsection{Market Development Strategy}

Market development strategy depends on the fact that customers prefer and purchase a business's existing products in new markets rather than the rival products (Kumar, 2010:96). Market development to boost selling is achieved by accessing to new segments and turning nonusers into customers of the business (p.320). Therefore, new geographic areas, new departments with demographic qualities, new institutional markets or market departments with new life forms might be among the aims of a business. Businesses are in search of new users for their existing products. The main danger in this strategy is that the brand might fail because it hasn't understood customer characteristics, needs and demands adequately and clearly (Schultz, 2004:7-9). Market development approach requires more extensive evaluation of market system. Determining the players in the market, their strengths and their roles in the value chain is crucial. Also, evaluation of the new probable players in the market is necessary during decision making. Evaluation of existing and potential players is the basic for market-oriented solutions and decisions of business (Lusby, 2006:341-343).

Businesses try to determine new opportunities that might be useful for their development. In this context, it is important to find and get into new markets (Kotler \& Keller, 2011:43). With the effect of globalisation on competition, businesses have had to make a choice about which international markets to get into (Caves \& Mehra, 1986:448). Success of market development strategy primarily requires understanding the market characteristics from customer's perspective and comparing the products with the rivals in the market. This determination is necessary to determine appropriate business targets and strategies for the market. When a business enters a country it has determined, it can also expand its market to other countries showing similar characteristics (McDonald, 2006:125). Because the effect of social and political institutions on market development strategy shows discrepancies according to different countries and regions, these factors should be analysed carefully during decision-making (Casson \& Lee, 2011:37).

Accurate market selection for investment is a crucial decision for businesses in international markets within the scope of development strategy (Nowak, 1997: 93). Businesses focused on new markets should develop their strategies accordingly. In this process, after defining the country upon general principles, customer segments are determined upon specific criteria (Steenkamp \& Hofstede, 2002:208). While defining the countries, the primary criteria are trade, economic, political and cultural aspects and then the second stage involves ranking the countries according to their weights in these aspects (Cavusgil, 2004:607). Businesses that want to expand to international markets and increase their selling and profitability are also supported by state policies. The biggest deterrent for businesses to develop international markets is lack of information about foreign markets (Mullen, 2008: 47-54).

\section{Research Methodology}

One of the leading brands in its sector with its superior technology and production diversity, Güral Porcelain has been active since 1989 and exports to 52 countries. Güral Porcelain management have been planning to get into new foreign markets to expand their trade network. Therefore, the management is faced with a problem of determining the most appropriate new foreign market to invest for their products. In this study, the most suitable new market for Güral Porcelain to invest within the scope of market development strategy was determined using AHP.

One of the Multi Criteria Decision Making (MCDM) techniques, AHP was developed in 1976 by Thomas L. Saaty (Saaty, 2000). AHP method has long been used in many areas like logistics and manufacturing decisions due to its validity and ease of use (Ho, 2008). AHP takes both numeric and nonnumeric criteria into account during problem solution process for decision-making and presents decision problems within a hierarchic structure so as to involve multiple periods, decision-maker and criteria (Koç \& Burhan, 2014). AHP decision process is basically comprised of five steps: The first and most ctucial step of the process is formation of the hierarchic structure, namely the model, of the decision problem by determining the target, alternatives, criteria and subcriteria, if any, of the decision problem (Wind \& Saaty, 1980). Especially in complex decision problems, it is important to determine the criterion. For this purpose, the literature and experts are consulted. The hierarchic structure of a decision problem involves the target, alternatives, criteria and subcriteria, if any. Figure 2 presents the general image of hierarchic structure. 


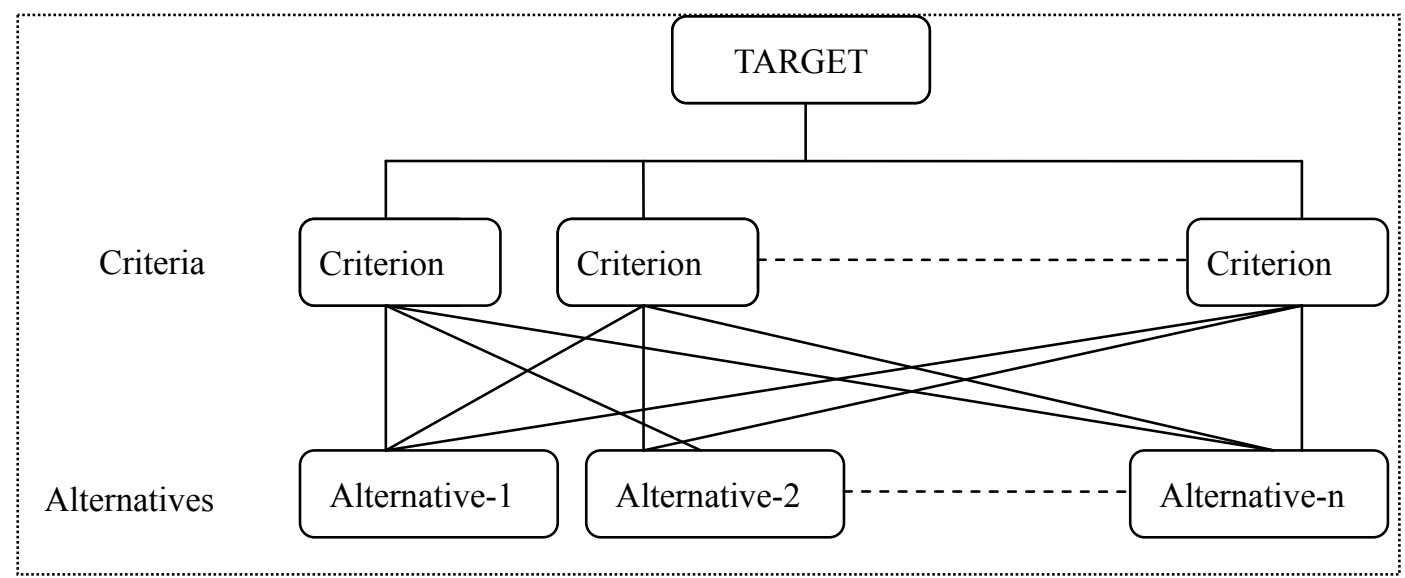

Figure 2. General structure of the hierarchy (Saaty, 2000)

The second step of the process is data acquisition during which data are gathered through paired comparison. In paired comparison, the decision-maker is asked to paired-wisely compare the main criteria taking the target into account, the sub-critaria taking every main criterion into account and the alternatives taking all the criteria into account. In these comparisons, relative importance scale valued between 1 and 9 developed by Saaty as seen in Table 1 (Saaty, 2001).

Table 1. 1-9 scale used in paired comparisons

\begin{tabular}{lll}
\hline $\begin{array}{l}\text { Importance } \\
\text { Degree }\end{array}$ & Definition & Explanation \\
\hline $\mathbf{1}$ & Equal importance & The two compared elements are of equal importance. \\
$\mathbf{3}$ & Medium importance & One element is more important than the other at medium level. \\
$\mathbf{5}$ & Strong Importance & One element is more important than the other at strong level. \\
$\mathbf{7}$ & Very strong importance & One element is more important than the other at very strong level. \\
$\mathbf{9}$ & Extreme importance & One element is more important than the other at extreme level. \\
$\mathbf{2 , 4 , 6 , 8}$ & Intermediate values & Importance levels used if no decision can be made between two importance levels. \\
\hline
\end{tabular}

Resource: Saaty, 2001.

Paired comparisons give paired comparison matrix and after obtaining all paired comparison matrices, their inconsistency rates are computed to determine the probable erroneous evaluations of decision-maker in comparisons. While some resources say that inconsistency rate should be smaller than 0.10 for consistency, some others accept smaller than 0.20 adequate (Cox, 2000; Soma, 2003). As inconsistency rate converges to 0, consistency of decisions will increase accordingly. Therefore, if inconsistency rate has unacceptable values, the decision-maker should reconsider his/her judgements. If inconsistency rate isn't at desired level in all matrices, paired comparsions for the relevant matrices should be repeated. On the other hand, if inconsistency rate is at desired level, it can be continued with the following step.

The third step is synthesis. At this step, the decisions taken from the decision-maker through paired comparisons are analysed and their importance levels of alternatives and criteria are determined. At the final step of AHP, the best alternative is determined according to the relative importance values acquired through synthesis. Thus, the best decision has been taken for decision-making problem and is presented to decision-makers.

AHP is a precious method for developing marketing strategies and is useful in determining not only marketing strategies that allow achieving both customer and business targets but also effective location approach. During planning process, it activates executives of strategic business units and top executives. It entails a process that requires meticulous situation analysis, creativity in the development of strategic alternatives and evaluation of the alternatives rationally. This process not only allows the management to integrate different perspectives but also helps to achieve an agreement despite different opinions. Instead of long reports, it produces short operational planning documents. It is also a tool in achieving various functional efforts and their harmony while applying business strategies. Besides being a process urging meticulous analyses, it is also a continuous method because it allows upgrading and necessary changes (Wind, 1987: 287). 
In this context, AHP can guide marketing strategies with its use while determining target market and distribution channels, developing and evaluating new product concepts and forming a marketing mix (Wind and Saaty, 1980, 642). Subramanian\&Ramanathan (2012:215-241) emphasize the importance of AHP for businesses to develop effective solutions in managerial decisions at points determined by researcher and executives. Also, Boer et al. (2001:75-89); Dulmin and Mininno, (2003:177-187); Sonmez, (2006:1-34) state that AHP is an effective solution tool in the most appropriate supplier selection process among the potential suppliers for businesses in terms of quality. Liao (2011: 831) made use of analytic hierarchy process to develop new products at the most appropriate price level depending on the market characteristics. Tao and Qian (2014:285-288), by focusing on customer demand and market segments, integrated international market classification of automobile industry with strong characteristics of brands. In that study, by using AHP, target market and cars appropriate for that market were determined for Chinese car brands. AHP has also become an effective method used in the process of selecting the most suitable foreign market. Businesses evaluate foreign markets with AHP using weighting method in terms of their characteristics, advantages and thus seize the opportunity of determining the best foreign market for themselves (Lesmes, Buitrago, \& Cendales, 2009:14; Priya \& Venkatesh, 2012:143-153). Abari et al. (2012:6297) used AHP in selecting target market and stated that businesses can decrease their costs and increase their profitability, quality and work-performance by means of selecting the appropriate target market. Kariznoee, Bijandi, Maddah and Mogharabi (2014:466), in their study to determine important main and sub-criteria in selecting target market in food industry, determined four main criteria the most important of which is cost criterion and the others are market size, competition environment and culture. Seçme, Bayrakdaroğlu and Kahraman (2009:11699) used this method while determining the priorities of five top banks in Turkish banking sector according to financial and non-financial criteria within the scope of service marketing.

\section{Analysis and Results}

In the this study, decision problem of Güral Porcelain involving various criteria soluble and insoluble numerically was solved using AHP method. At the first stage of the process, the problem was defined, alternatives and criteria were determined with the literature and export executive of Güral Porcelain were consulted. As a result of the meetings, it was determined that the alternative most appropriate new markets were Northern Iraq, Brasil and Cuba. The criteria were determined upon literature review and interviews with the decision-maker. Total eight main criteria were determined in the study: operating assets, communication infrastructure of the target market, economic growth rate, proximity to other markets, competitive advantage in the target market, demand, functioning of the legal system and trade agreements with the target market-exemption. At the second stage, hierarchic model was set up as shown in Fig.3.

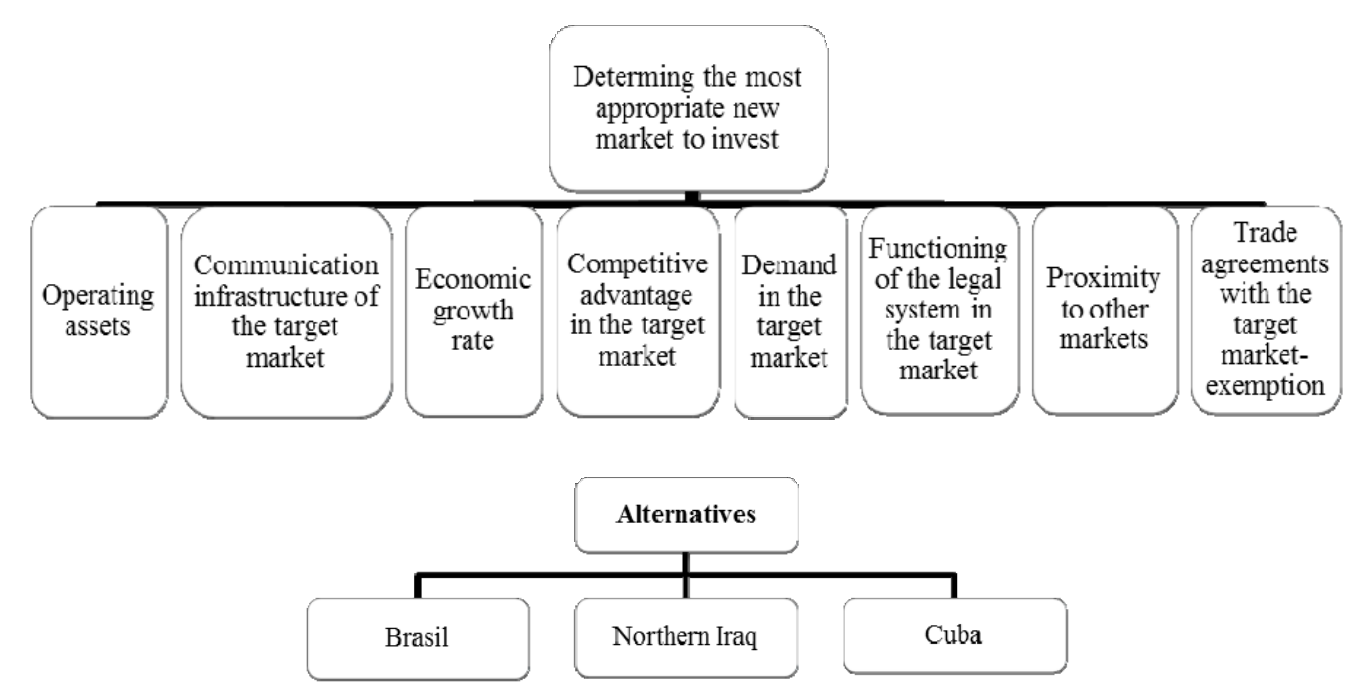

Figure 3. Hierarchy model developed for Güral Porcelain's decision problem

Afterwards, paired comparisons were conducted using Saaty's 1-9 scale and the data were obtained by taking the judgements of the decision-maker. After completing the paired comparisons, paired comparison matrices were obtained as seen in Table 2. 
Table 2. Paired comparison matrix for the main criteria

\begin{tabular}{|c|c|c|c|c|c|c|c|c|}
\hline & $\begin{array}{l}\text { Operating } \\
\text { Assets }\end{array}$ & $\begin{array}{l}\text { Communication } \\
\text { Infrastructure of } \\
\text { Target Market } \\
\text { (B) }\end{array}$ & $\begin{array}{l}\text { Economic } \\
\text { Growth } \\
\text { Rate of } \\
\text { Target } \\
\text { Market } \\
\text { (C) } \\
\end{array}$ & $\begin{array}{l}\text { Competitive } \\
\text { Advantage in } \\
\text { Target } \\
\text { Market } \\
\text { (D) } \\
\end{array}$ & $\begin{array}{l}\text { Demand } \\
\text { in Target } \\
\text { Market } \\
\text { (E) } \\
\end{array}$ & $\begin{array}{l}\text { Functioning } \\
\text { of Legal } \\
\text { System in } \\
\text { Target } \\
\text { Market } \\
\text { (F) }\end{array}$ & $\begin{array}{l}\text { Proximity } \\
\text { of Target } \\
\text { Market to } \\
\text { Other } \\
\text { Markets } \\
\text { (G) } \\
\end{array}$ & $\begin{array}{l}\text { Trade } \\
\text { Agreements } \\
\text { with Target } \\
\text { Market and } \\
\text { Exemptions } \\
\text { (H) }\end{array}$ \\
\hline (A) & 1 & 7 & 7 & 7 & $1 / 9$ & $1 / 7$ & 1 & $1 / 9$ \\
\hline (B) & $1 / 7$ & 1 & $1 / 2$ & $1 / 2$ & $1 / 9$ & $1 / 7$ & $1 / 3$ & $1 / 9$ \\
\hline (C) & $1 / 7$ & 2 & 1 & 1 & $1 / 9$ & $1 / 7$ & $1 / 3$ & $1 / 9$ \\
\hline (D) & $1 / 7$ & 2 & 1 & 1 & $1 / 9$ & $1 / 5$ & $1 / 3$ & $1 / 7$ \\
\hline (E) & 9 & 9 & 9 & 9 & 1 & 3 & 7 & 2 \\
\hline$(\mathrm{F})$ & 7 & 7 & 7 & 5 & $1 / 3$ & 1 & 3 & $1 / 2$ \\
\hline (G) & 1 & 3 & 3 & 3 & $1 / 7$ & $1 / 3$ & 1 & $1 / 7$ \\
\hline$(\mathrm{H})$ & 9 & 9 & 9 & 7 & $1 / 2$ & 2 & 7 & 1 \\
\hline
\end{tabular}

As seen in Table 2, "Operating Assets" criterion has an importance level at «very strong level» compared with "Communication Infrastructure of Target Market", "Economic Growth Rate of Target Market" and "Competitive Advantage in Target Market" criteria, its importance level is low at "very strong level» compared with "Functioning of Legal System in Target Market" criterion. Judgements of the decision-maker for the other criteria are interpreted similarly.

After obtaining all the paired comparison matrices, incoherence rate was checked for each matrix. At this stage and the analysis stage, Expert Choice package program was used. The matrices wree decided to be coherent because incoherence rate for all the criteria was between 0 and 0,09 and these values were below 0,10 . At the analysis stage of the process, weights were computed for criteria and alternatives and the most appropriate market was selected. Fig. 4 presents the relative importance levels obtained as a result of the analyses.

Accordingly, it is seen that "Demand in Target Market" criterion is the most important criteria for Güral Porcelain in selecting potential target market with (0.350) importance value followed by Trade Agreements with Target Market and Exemptions (0.274), Functioning of Legal System in Target Market (0.175), Operating Assets (0.079), Proximity of Target Market to Other Markets (0.054), Competitive Advantage in Target Market (0.026), Economic Growth Rate of Target Market (0.024) and Communication Infrastructure of Target Market $(0.019)$.

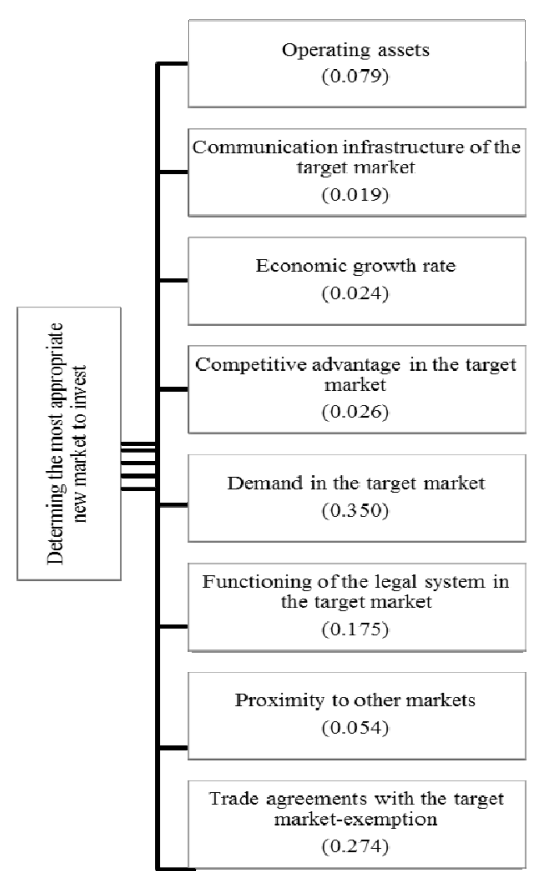

Figure 4. Relative importance values for the problem of Güral Porcelain's selection of the most suitable new market 
The last stage of AHP process involves determination of the most appropriate market and application of the results for which relative importance levels were computed for alternatives and are presented in Table 3 . As seen in Table.3, Northern Iraq alternative is determined to be the most appropriate new market to invest. The findings were presented to Güral Porcelain Export Department together with their interpretations.

Table 3. Relative importance values for alternatives
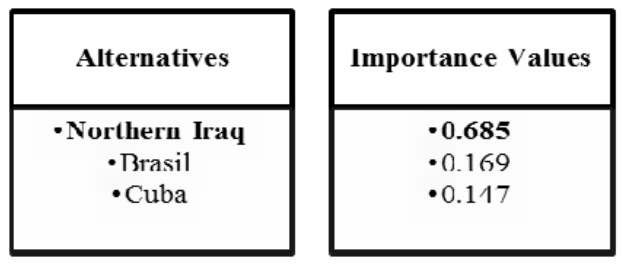

\begin{tabular}{|c|}
\hline Rank \\
\hline$\cdot \mathbf{1}$ \\
$\cdot 2$ \\
$\cdot 3$ \\
\hline
\end{tabular}

\section{Discussion and Implications}

Sustaining their existence and advancing within the global competitive environment are possible for businesses if they can take the appropriate opportunities for them. Businesses determine and apply growth strategies according to the interaction between environmental elements, business structure and strategies. Businesses seek for new markets for their existing products and evaluate the markets appropriate for their strategies in terms of their characteristics. Sakarya et al. (2006), emphasizes the importance of four basic critical factors to develop international markets. These are future potential of the market, managemet of cultural differences, positive attitudes of customers to foreign products and businesses with their supportive and developing local industries, development of expanding markets and taking the resource opportunities (Sakarya et al., 2006:208-230). White and Griffith (1997:173) advocate that cost, customer and innovation oriented business strategies are basic in determining international markets and target market's behavioural traits. Rahman (2006:73) points out that while determining the target country, cost and political indicators of that country should be taken into account. O'Farrell and Wood (1994:243-261) prenet the main determiners in international market selection as market size, geographical proximity, cultural difference, market similarity, state regulations, international experiences of the business.

Having been active in porcelain sector for a long time, Güral Porcelain is also looking for new markets to export within the scope of market development strategy. Because the problem of determining the most appropriate market to invest involves tangible/intangible and many conflicting criteria, it is a complex decision problem. Therefore, AHP is a suitable method for such a problem. In this study, the problem of Güral Porcelain to determine the most appropriate new market to invest has been studied. Firstly, the problem was defined and criteria and alternatives were determined with the decision-maker. After building a hierarchic model for decision-problem, by doing paired comparisons, paired comparison matrices were obtained. Inconsistency rates were computed for the matrices and, determining that all the matrices are consistent, their relative importance levels were computed. According to the relative importance levels shown in Fig.4, "demand in target market" was found to be the most important criterion for Güral Porcelain to determine a new market. Relative importance levels of the alternatives were also computed and according to these values shown in Table.3, Northern Iraq alternative was determined to be the most suitable market.

Results from this study provide important implications for export executive of Güral Porcelain to determining the most appropriate new foreign market to invest for their products. Operating assets, communication infrastructure of the target market, economic growth rate, proximity to other markets, competitive advantage in the target market, demand, functioning of the legal system and trade agreements with the target market-exemption criteria's influence to determining the most appropriate new foreign market to invest for their products supported by literature. The conclusions of the study were presented to Güral Porcelain Export Department as a written report and accepted by the decision-maker as applicable.

\section{Further Research}

The fact that the study deals with a real-life problem and puts forth an applicable solution to it is an important contribution in terms of providing a course of action to businesses encountering similar challenges. On the other hand, criteria determinable upon literature review and interviews with the decision-maker in different sector or other business. In this way, different criteria and markets pollable for business in different sector or business in the same sector. 


\section{References}

Aaker, D. A., \& McLoughlin, D. (2010). Strategic Market Management- Global Perspectives (1st ed.). Wiley. Retrieved

from http://books.google.com.tr/books?id=tpW22FvYvn8C\&printsec=frontcover\&hl=tr\&source=gbs_ge_summa ry_r\&cad $=0 \# \mathrm{v}=$ onepage $\& \mathrm{q} \& \mathrm{f}=$ false

Abari, M. K., Nilchi, A. N., \& Hekmatpanah, M. (2012). Target Market Selection Using Fuzzy Analytic Hierarchy Process (AHP) and Technique for Order Preference by Similarity to İdeal Solution (Tposis). Methods African Journal of Business Management, 6(20), 6297. http://dx.doi.org/10.5897/AJBM11.2626

Ansoff, I. H. (1965). The Firm of the Future. Harvard Business Review, 43(5), 163-164.

Ansoff, I. H. (1975). Managing Strategic Surprise by Response to Weak Signals. California Management Review, 18(2), $26 . \quad$ Retrieved from http://eds.a.ebscohost.com/eds/pdfviewer/pdfviewer?vid=2\&sid=2f3ff357-148d-408b-8384-1278b1584b63 $\% 40$ sessionmgr4001\&hid $=4210$

Ansoff, I. H. (1977). Strategy Formulation as a Learning Process: An Applied Managerial Theory of Strategic Behavior. International Studies of Management \& Organization, 7(2), 58-77. Retrieved from http://eds.a.ebscohost.com/eds/pdfviewer/pdfviewer?vid=4\&sid=92a4d94e-543f-4877-8559282bb2da35d6 $\% 40$ sessionmgr4004\&hid $=4210$

Ansoff, I. H. (1987). The Emerging Paradigm of Strategic Behavior. Strategic Management Journal, 8, 514. http://dx.doi.org/10.1002/smj.4250080602

Ansoff, I. H.. (1957). Strategies for Diversification. Harvard Business Review, 35(5), 114-115. Retrieved from http://foswiki.org/pub/Sandbox/SimiWiki/Strategies_for_diversification.pdf

Arkolakis, C. (2008). Market Penetration Costs and New Consumers Margin in International Trade. NBER Working Paper No. 14214, p.31. Retrieved from http://www.nber.org/papers/w14214.pdf

Boer, L., Labro, E., \& Morlacchi, P. (2001). A Review of Methods Supporting Supplier Selection. European Journal of Purchasing \& Supply Management, 7, 75-89. http://dx.doi.org/10.1016/S0969-7012(00)00028-9

Cadle, J., Paul, D., \& Turner, P. (2010). Business Analysis Techniques- 72 Essential Tools for Success. British Informatics Society Limited, UK. http://bcs.org/upload/pdf/business-analysis-techniques.pdf

Callaghan, B., \& Morley, C. (2002). The Hierarchy of Target Market Selection Criteria. ANZMAC 2002 $\begin{array}{lllll}\text { Conference } & \text { Proceedings, } & \text { p. } & \text { Retrieved } & \text { from }\end{array}$ http://www.anzmac.org/conference_archive/2002/papers/pdfs/p138_callaghan.pdf

Casson, M., \& Lee, J. S. (2011). The Origin and Development of Markets: A Business History Perspective. Business History Review, 85, 37. http://dx.doi.org/10.1017/S0007680511000018

Caves, R. E., \& Mehra, S. K. (1986). Entry of Foreign Multinationals into U.S. Manufacturing Industries. In M. E. Porter (Ed.), Competition in Global Industries (p. 449). Harvard Business School Press. Retrieved from http://books.google.com.tr/books?hl=tr\&id=vhzv3Dfb8MIC\&q=Entry+of+Foreign+Multinationals + into $+U$. S. + Manufacturing + Industries $\# \mathrm{v}=$ snippet\&q=Entry\%20of\%20Foreign\%20Multinationals\%20into\%20U.S. $\% 20$ Manufacturing $\% 20$ Industries\& $\mathrm{f}=$ false

Cavusgil, T., Kiyak, T., \& Yeniyurt, S. (2004). Complemenntary Approaches to Preliminary Foreign Market Opportunity Assessment: Country Clustering and Country Ranking. Industrial Marketing Management, 33, 607. http://dx.doi.org/10.1016/j.indmarman.2003.10.005

Chandler, A. D. (1959). Integration and Diversification as Business Strategies-An Historical Analysis. Massachusetts Institute of Technology, p. 73. Retrieved from http://www.thebhc.org/publications/BEHprint/v019/p0065-p0073.pdf

Cilley, J. (2011). A Road Map for Growing Your Business. Business NH Magazine, 28(10), 32.

Cooper, R., \& Edgett, S. (2010). Developing A Product Innovation and Technology Strategy for Your Business. Research Technology Management, 53(3), 33-40. Retrieved from http://www.stage-gate.com/downloads/wp/wp_39.pdf

Cox, A. M., Alwang, J., \& Johnson, T.G. (2000). Local preferences for economic development outcomes: Analytical hierarchy procedure. Growth and Change Summer, 31, 341-366. Retrieved from 
http://eds.a.ebscohost.com/eds/pdfviewer/pdfviewer?sid=ffac2248-83f5-4f2f-9775-1f0a77800cb1\%40sessi onmgr $4002 \&$ vid $=3 \&$ hid $=4210$

Crawford, C. M. (1972). Strategies for New Product Development, Business Horizons. School of Business $\begin{array}{lllll}\text { Indiana University, } & \text { 49-58. } & \text { Retrieved }\end{array}$ http://deepblue.lib.umich.edu/bitstream/handle/2027.42/33991/0000263.pdf

Crosby, L. A. (2012), Relational Investing. Marketing Management, p. 12. Retrieved from https://archive.ama.org/archive/ResourceLibrary/MarketingManagement/Pages/2012/Winter/lawrence-cros by-innovation-growth-portfolio-ansoff-matrix.aspx

Dulmin, R., \& Mininno, V. (2003), Supplier Selection Using a Multi-Criteria Decision Aid Method. Journal of Purchasing \&Supply Management, 9, 177-187. http://dx.doi.org/10.1016/S1478-4092(03)00032-3

Gotzsch, J., Chanaron, J. J., \& Birhall, D. (2006). Product Development with A Focus on Attractive Product Expression: An Analysis of Case Studies. International Journal of Product Development, 3(3-4), 467-476. http://dx.doi.org/10.1504/IJPD.2006.009903

Ho, W. (2008). Integrated Analytic Hierarchy Process and Its Applications-A Literature Review. European Journal of Operational Research, 186, 211-228. http://dx.doi.org/10.1016/j.ejor.2007.01.004

Johnson, G., Scholes, K., \& Whittington, R. (2005). Exploring Corporate Strategy, Text and Cases (7th ed.). Prentice Hall, England. Retrieved from http://alhaidari.net/zahir/Exploring.pdf

Kariznoee, A., Bijandi, M., Maddah, M. G., \& Mogharabi, V. (2014). Using a Combined Method of Hierarchical Analysis and Monte Carlo Simulation in order to Identify and Prioritize the Target Market Selection Criteria (Case Study: Food Distribution Companies of Mashhad-Iran). Applied Mathematics in Engineering, Management and Technology, 2(2), 466. Retrieved from http://amiemt-journal.com/test/vol2-2/50.pdf

Koç, E., \& Burhan, H. A. (2014). An Analytic Hierarchy Process (AHP) Approach to a Real World Supplier Selection Problem. A Case Study of Carglass Turkey. Global Business and Management Research: An International Journal, $6(1), \quad 1-14 . \quad$ Retrieved from http://www.gbmr.ioksp.com/pdf/vol.\%206\%20no.\%201/Ko\%C3\%A7\%20\&\%20Burhan.pdf

Kotler, P. (2000). Marketing Management (Millenium Edition). Prentice-Hall, Inc., New Jersey.

Kotler, P. (2003). Marketing Insights from A to Z- 80 Concepts Every Manager Needs To Know. John Wiley \& Sons, Inc. Retrieved from http://www.slideshare.net/aeldeeb/ebook-kotler-philip-marketing-insights-from-a-to-z

Kotler, P., \& Keller, K. (2011). Marketing Management (14th ed.). Prentice Hall, New Jersey.

Krishnan, V., \& Ulrich, K. T. (2001). Product Development Decisions: A Review of the Literature. Management Science, 47(1), 1-21. http://dx.doi.org/10.1287/mnsc.47.1.1.10668

Kumar, D. (2010). Enterprise Growth Strategy: Vision, Planning and Execution. Gower Publishing Limited, England.

Retrieved

from http://www.amazon.ca/Enterprise-Growth-Strategy-Planning-Execution/dp/0566091984\#reader_056609198 4

Lesmes, D., Buitrago, L., \& Cendales, C. (2009). Application of the Analytic Network Process (ANP) to Select New Foreign Markets to Export Software Services: Study of Colombian Firms. Proceedings of the International Symposium on the Analytic Hierarchy Process 2009, 14. Retrieved from http://www.isahp.org/2009Proceedings/Final_Abstracts/43_Lesmes_Buitrago_Cendales_ANPinSelectingFo reignMarketsForExporting_REV_FIN-a.pdf

Liao, C. N. (2011). Fuzzy Analytical Hierarchy Process and Multi- Segmant Goal Programming Applied to New Product Segmented under Price Stategy. Computer \& Industrial Engineering, 61, 831. http://dx.doi.org/10.1016/j.cie.2011.05.016

Lombriser, R., \& Ansoff, I. (1995). How Successful Intrapreneurs Pilot Firms Through The Turbulent 1990s. Journal of Strategic Change, 4, 95-108. http://dx.doi.org/10.1002/jsc.4240040204

Lowy, A., \& Hood, P. (2004). The Power of the $2 * 2$ Matrix. John Wiley and Sons Inc. Retrieved from http://books.google.com.tr/books?id=RvPNf89a7FYC\&printsec=frontcover\&hl=tr\&source=gbs_ge_summa ry_r\&cad $=0 \# v=$ onepage $\& q \& \mathrm{f}=$ false 
Lusby, F. (2006). Useful Principles for Adopting A Market Development Approach for Enterprise Development Organizations. International Journal of Emerging Markets, 1(4), 341-343. http://dx.doi.org/10.1108/17468800610703388

McDonald, M. (2007). Marketing Plans: How to Prepare Them, How to Use Them (6th ed.). Jordan Hill. Retrieved http://www.amazon.co.uk/Marketing-Plans-How-Prepare-Them/dp/0470669977\#reader_0470669977

McDonald, M., \& Wilson, H. (2011). Marketing Plans: How to Prepare Them, How to Use Them (7th ed.). John Wiley \&Sons Ltd, UK. Retrieved http://www.amazon.co.uk/Marketing-Plans-How-Prepare-Them/dp/0470669977\#reader_0470669977

McKaskill, T. (2010). Ultimate Growth Strategies- A Practical Guide to Engineer High Growth into Your Business, Breakthrough Publications, RBN:B2173298N, Australia. Retrieved from http://www.drexit.net/resources/McKaskill-Ultimate-Growth-Strategies.pdf

Meyer, K., \& Tran Y. T. T. (2006). Market Penetration and Acquisition Strategies for Emerging Economies, Long Range Planning, 39(2), 179. $\quad$ Retrieved from http://klausmeyer.co.uk/publications/2006_meyer_tran_LRP_final.pdf

Mullen, M. R. (2008). Foreign Market Analysis. Irish Marketing Review, 20(1), 47-54. Retrieved from http://eds.a.ebscohost.com/eds/pdfviewer/pdfviewer?sid=30a405d7-9089-4722-805e-5fd381a40093\%40ses sionmgr 4003 \&vid $=4 \&$ hid $=4202$

Nowak, J. (1997). International Market Selection: Developing a Region-Specific Procedure for Central and Eastern Europe. Journal of Transnational Management Development, 3(1), 93. http://dx.doi.org/10.1300/J130v03n01_07

O'Farrell P. N., \& Wood, P. A. (1994). International Market Selection by Business Service Firms: Key Conceptual and Methodological Issues. International Business Review, 3(3), 243-261. http://dx.doi.org/10.1016/0969-5931(94)90004-3

Porter, M. E. (1996). What Is Strategy?, Harward Business Review, pp. 6-17. Retrieved from http://weaddvalue2.web12.hubspot.com/Portals/188908/docs/hbr.what\%20is\%20strategy.pdf

Preston, G. S. (1990). Fast-Cycle Product Development. Engineering Management Journal, 2(2), 11. Retrieved from http://s2m.cyberoptik.net/wp-content/uploads/2014/05/Fast-Cycle-Product-Development.pdf

Priya, P., \& Venkatesh, A. (2012). Integration of Analytic Hierarchy Process with Regression Analysis to Identify Attractive Locations for Market Expansion. Journal of Multi-Criteria Decision Analysis, 19, 143-153. http://dx.doi.org/10.1002/mcda.1471

Rahman, S. (2006). International Market Selection Process: An Investigation of the Relevance of Business Operating Environment. Journal of International Business Research, 5(1), 73. Retrieved from http://arrow.uws.edu.au:8080/vital/access/manager/Repository/uws:4583

Saaty, T. L. (2000). Fundamentals of Decision Making and Priority Theory with The Analytic Hierarchy Process. Vol VI of the AHP Series, RWS Publications.

Saaty, T. L. (2001). The analytic network process. Pittsburgh: RWS Publications.

Sakarya, S., Eckman, M.. \& Hyllegard, K. H. (2007). Market Selection for International Expansion- Assessing Opportunities in Emerging Markets, International Marketing Review, 24(2), 208-230. http://dx.doi.org/10.1108/02651330710741820

Schultz, R. L. (2004). A Note on the Product-Market Growth Matrix. University of Iowa. Retrieved from http://www.theproduct.com/faculty/papers/product-market.pdf

Seçme, N. Y., Bayrakdaroğlu, A., \& Kahraman, C. (2009). Fuzzy Performance Evaluation in Turkish Banking Sector using Analytic Hierarchy Process and TOPSIS. Expert Systems with Applications, 36(9), 11699. http://dx.doi.org/10.1016/j.eswa.2009.03.013

Skrt, B., \& Antoncic, B. (2004). Strategic Planning and Small Firm Growth: An Empirical Examination. Managing Global Transitions, 2(2), 108. $\quad$ Retrieved from http://www.fm-kp.si/zalozba/ISSN/1581-6311/2_107-122.pdf

Soma, K. (2003). How to İnvolve Stakeholders in Fisheries Management—A Country Case Study in Trinidad and Tobago. Marine Policy, 27, 47-58. http://dx.doi.org/10.1016/S0308-597X(02)00050-7 
Sönmez, M. (2006). A Review and Critique of Supplier Selection Process and Practices. Business School Occasional Papers Series, 1, 1-34. $\quad$ Retrieved from https://dspace.lboro.ac.uk/dspace-jspui/bitstream/2134/2160/3/2006-1.pdf

Steenkamp, J. E. M., \& Hofstede, F. T. (2002). International Market Segmentation: Issues and Perspectives. International Journal of Research in Marketing, 19, 208. Retrieved from http://faculty.mccombs.utexas.edu/frenkel.terhofstede/publpapers/IJRM\%202002.pdf

Subramanian, N., \& Ramanathan, R. (2012). A Review of Applications of Analytic Hierarchy Process in Operations Management. International Journal of Production Economics, 138, 215-241. http://dx.doi.org/10.1016/j.ijpe.2012.03.036

Şener, H. Y., \& Behdioğlu, S. (2013). Müşteri Sadakati Oluşturmada Müşterinin Algıladığı Değer, Memnuniyet ve Rakip İşletmeye Geçme Maliyeti: Bir Spor Merkezinde İstatistiksel Uygulama. Selçuk Üniversitesi Sosyal Bilimler Enstitüsü Dergisi, 30, 167.

Takeuchi, H., \& Nonaka, I. (1986). The New New Product Developmant Game. Harwrad Business Review, 137-146. $\quad$ Retrieved from https://www.iei.liu.se/fek/frist/723g18/articles_and_papers/1.107457/TakeuchiNonaka1986HBR.pdf

Tao, X., \& Qian, Y. (2014). Chinese Automobile Brand International Marketing Target Market Selection Model Based on AHP. International Journal of Business and Social Science, 5(1), 285-288. Retrieved from http://www.ijbssnet.com/journals/Vol_5_No_1_January_2014/32.pdf

White, S., \& Griffith, D. (1997). Combining Corporate and Marketing Strategy for Global Competitiveness. Marketing Intelligence \& Planning, 15(4), 173. http://dx.doi.org/10.1108/02634509710185289

Wind, Y. (1987). An Analytic Hierarchy Process Based Approach to the Design and Evaluation of a Marketing Driven Business and Corporate Strategy. Mathl Modelling, 9(3-5), 287. http://dx.doi.org/10.1016/0270-0255(87)90484-2

Wind, Y., \& Saaty, T. L. (1980). Marketing applications of the analytic hierarchy process. Management Science, 26(7), 641-658. Retrieved from http://yunus.hacettepe.edu.tr/ aulucan/pdf/Marketing.pdf

Yelkur, R., \& Herbig, P. (1996). Global Markets and The New Product Development Process. Journal of Product and Brand Management, 5(6), 38-43. http://dx.doi.org/10.1108/10610429610152822

Yli-Renko, H., \& Janakiraman, R. (2008). How Customer Portfolio Affects New Product Development in Technology-Based Entrepreneurial Firms. Journal of Marketing, 72, 144. Retrieved from https://msbfile03.usc.edu/digitalmeasures/ylirenko/intellcont/Yli-Renko\%20and\%20Janakiraman\%2009_08 $-1 . p d f$

\section{Copyrights}

Copyright for this article is retained by the author(s), with first publication rights granted to the journal.

This is an open-access article distributed under the terms and conditions of the Creative Commons Attribution license (http://creativecommons.org/licenses/by/3.0/). 